\title{
An Assessment on the Constitution of Nepal 2015
}

\author{
Lecturer, Dilli Raj Gautam, PhD Scholar
}

Department of Political Science, Tribhuvan University, Dhaulagiri

Multiple Campus, Baglung

\begin{abstract}
This paper aims to critically examine the major features, strengths and weaknesses of the present constitution of Nepal (2015) applying the fundamental instruments of constitutionalism as a measuring rod. The Constitutional discourse of Nepal moved through seven Constitutions so far. It can be better linked to a laboratory of constitutional experiments of the constitutions of 1948, 1951, 1959, 1962, 1990, 2007, and 2015. The present constitution of Nepal (2015) was promulgated with the motive of political and social transformation strengthening democracy, human rights, ensuring equality, liberties and social justice to the people. In order to explore the features, strengths and weaknesses of the constitutions available texts and other materials on the constitution were collected first and then the content analysis method was followed to explore the major features, strengths and weaknesses of the constitution. Based on the analysis, dynamism and flexibility, comprehensive catalogue of fundamental rights and inclusiveness and proportional representation were found as the major features. Incorporation of adequate economic, social and cultural rights including group rights empowerment of women and minorities inclusiveness and proportional representation are the major attributes of the present constitution. In spite of popular acceptance of the people's verdict and wider inclusion of progressive arrangement the constitution still conceives some weaknesses on vague and clumsiness of preamble, disparity on citizenship issues and constituency delineations, enlistment of ambitious and unenforceable rights and composition of politically shadowed judiciary.
\end{abstract}

Keywords : Constitution, democracy, federal, parliamentary. 


\section{Introduction}

The Constitution is a fundamental political and legal document of the land. It sets out the structure of the government of a nation. It is promulgated to exercise sovereignty. It determines power and functions with the government and guarantees rights for the citizens with a reliable enforcement mechanism. "A constitution may be said to be a collection of principles according to which power of government, the right of the governed and the relation between two are adjusted" (Strong, 1973: 10). Strong outlines the constitution as a codified document of principles which demarcates the power and functions of the government and the governed altogether. Asserting over constitution, Grimm focuses on two different meanings, "Firstly, it refers to the nature of a country with reference to its political conditions. Secondly, the constitution refers to a law that concerns itself with the establishment and exercise of political rule" (Grimm, 2017: 3 ). Thus, the constitution refers to the empirical and normative concept of governance. "The Constitution remains a guiding principle that modules a nation as per the dreams and aspirations of the people of a specific country" (Meena and Bhattacharjee, 2016: 19). In short, the constitution is a supreme law of a nation which lays down the framework defining fundamental political principles, establishes the structure, procedures, powers and duties of the government institutions, and sets out fundamental rights, directive principles and the duties of the citizens whether it is written, unwritten, enacted or developed document.

The history of modern constitutional development begins with promulgation of the Constitution of United States of America in 1787. However, the United Kingdom, the motherland of parliamentary democracy and human rights with the model of unwritten constitution, had already presented people's rights in Magna Carta 1215 and Bill of Rights 1689. France established 
its Constitution in 1791 as an outcome of French revolution. China declared its first constitution in 1954 and made two more records in 1975 and 1978. Finally, China enacted the present constitution in 1982 (Dahal, 2017: 150). Similarly, India right after independence built its first constitution in 1950 and operates with more than 104 amendments. South Africa adopted its present constitution in 1996 incorporating the major characters contained in the Canadian Charter of Rights shortly after the introduction of the Interim Constitution of 1993 (Davis, Cheadle and Haysom, 1997:7).

The modern constitutions of the world work with four mutually contradictory characters; presidential, parliamentary, mixed (presidential plus parliamentary and socialist guided). Power and authority of the government are influenced by their model. The constitution building discourse of Nepal passes through different upheavals.

So far as it is concerned the constitutional development of Nepal it goes back to 1768 when the modern Nepal state was built. Royal edicts and key Hindu scriptures formed the law of the land. Right after the official visit of the then Prime Minister Jung Bahadur Rana he insisted to promulgate 'Muluki Ain' (the law of the land) to Surendra Bir Bikram Shah in 1854 (1910B.S.). It was the codification of the traditional approach of Hindu laws in common practice. The code remained the main source to 'administer justice' in Nepal for many years. The government of Nepal Act was an attempt to develop the framework of a parliamentary system with a bicameral legislative body. Even though the Prime Minister had been vested with the power to select the majority of the members of both houses and reject in any 'measure' even if it was passed by legislature (Tripathi, 2002: 21). 
After the government of Nepal Act, an interim constitution was established in the name of Interim Government of Nepal Act 1951 which restored the power to the king. The then King Tribhuvan had promulgated this constitution. The constitution of the kingdom of Nepal 1959 was adopted with the motive of conducting parliamentary elections. But King Mahendra Bir Bikram Shah seized this constitution in 1960 and controlled over the popularly elected government led by Nepali Congress leader B.P. Koirala. He introduced a new constitution in 1962 based on the Partyless Panchayat system pressurized the king to bow down and agree to take up democratic constitution and switch to constitutional monarchy. A parliamentary political party, arrogant democracy and cultivated Maoist insurgencies persuading in the name of avoiding all kinds of inequalities, injustice, corruption prevailing in the country. After the Narayanhiti Massacre, the successive King Gyanendra upheld sole power in his hand and started to oppress Maoist rebels and parliamentary parties at a time. His regressive step provided good room to the political parties and the Maoist to unite and fight collectively against the monocracy of the King. They made seven points of agreement and ultimately made the king kneel down in front of the people's power. Ultimately the interim constitution of Nepal 2007 was announced resulting in the termination of monarchy in Nepal. As per the provision of interim constitution, the election of the constituent assembly was held twice in 2008 and 2013 A.D. (Naidu, 2016: 7-8).

Consequently, eight years after the Interim Constitution, following a tortuous political process, the constituent assembly voted overwhelmingly (507 out of 601) to approve the new Constitution of Nepal 2015 (Singh, 2016: 16). It was the result of compromise between the major national political parties. It was written and adopted by a two-third majority of the Constituent 
Assembly elected by the people. It is based on the democratic principles, the rule of law, respect for human rights, and judicial independence (Subedi, 2017: 9). Clarity or definiteness, brevity, comprehensiveness, flexibility, declarations of fundamental rights, independent of judiciary and provisions of directive principles and state policies are the major values of a good constitution (Bhattarai, 2016: 17-20). Whether the Constitution of Nepal 2015 deserves these qualities or not is the important question to assess through the study. Therefore, this paper focuses on the major features, strengths and weaknesses arranged under the present Constitution of Nepal in the light of constitutionalism.

\section{Objectives and Methods}

The main objective of this paper is to explore the major features, strengths and weaknesses of the constitution of Nepal (2015) in the light of constitutionalism, liberal democracy and socialism.

Since the necessary information for this paper was borrowed from the available texts and other materials, it is based on more qualitative information. The sources of information were thus secondary sources. These sources include constitutions, books, journals, scholarly articles and seminar papers, etc. The paper then analyzes the content to explore major features, strengths and weaknesses under the present Constitution. The analysis is focused on the identification and description of key features, strengths and weaknesses based on the major ideals of good constitution and constitutionalism. 


\section{Major Features}

Dynamism and flexibility, comprehensive catalogue of fundamental rights and inclusiveness and proportional representation are the major features of the Constitution of Nepal (2015). The adoption of a federal, democratic and secular constitution in Nepal is a historic occasion. The new constitution embraces the principles of republicanism, federalism, secularism and inclusiveness.

The constitution of Nepal 2015 incorporates certain outstanding features including dynamism and flexibility. The century-long centralized unitary system with monarchy has transformed into a federal democratic republic with seven provincial states. The preamble of the constitution has declared the sovereign and state power remaining to the people. For the first time, in the constitutional discourse of Nepal, the present constitution has liberated naming acquired citizenship of both mother and father. The new constitution has stood for gender equality standardizing that any one out of the President and Vice President, the speaker and the deputy speaker, National Assembly President and Vice president, speaker and deputy speaker of the state Assembly should have mandatorily elected from women and different communities. The constitution has accommodated both direct and proportional election system in the ratio of 60 and 40 percent. Part 6 of the constitution has replaced the king by constitutional president and vice president (Naidu, 2016: 144).

Similarly, the constitution has anticipated a cabinet not exceeding more than 25 members. No one can be Prime Minister without being a member of the federal House of Representatives and to be a minister member of the parliament is mandatory. To reach in constitutional executive position such as President, vice President, Prime Minister, chief Justice, speaker, National 
Assembly Chairman, state Chief, Chief minister, state assembly speaker and heads of security agencies whether it is through election or nomination or appointment are only from the citizens by descent (Singh, 2019: 165-166). Likely, expecting the stability of the government, the motion of no confidence can be placed only in the interval of two years. The constitution has declared Nepal as a secular state defining 'secularism' means the sacred solemn of religious, cultural freedoms including protection of religion and culture handed down from time immemorial. The present constitution of Nepal has allowed space for making amendment any article whatever of the constitution except the provision of self- rule of Nepal, sovereignty, territorial integrity and sovereignty inherent in the people and also permits for referendum in major national issues. The provision of dynamism and flexibility of the constitution guarantees to make it a living document (Tripathi, 2016).

Comprehensive catalogue of fundamental rights is another notable feature of the new constitution. The constitution assesses the sustainable goals of human rights to persuade the objective of 'leave no one behind' integrating the crosscutting principles of human rights such as participation, accountability and nondiscrimination. The constitution is built to pay due respect to basic human rights and human dignity, the rule of law, social justice, equality and non-discrimination persisting to create a just, equitable, tolerant, open and socially inclusive society in which the potentiality of every individual could flourish and the needs of the most vulnerable are met (Sharma, 2020). The extensive list of fundamental rights in the constitution for the promotion of the welfare state seems to be an incomparable feature. Provision of the right of the physically handicapped persons, the right to food, sovereignty, Dalits, right to health and social security and free higher education, right to social security, 
right to employment look like ambitious arrangement against the real reach of the state resources (Tripathi, 2016: 128-129). This reflects that the fundamental rights are broadly mentioned in the constitution.

The other remarkable characteristic of the constitution of Nepal is inclusiveness and proportional representation. The new constitution emphasizes inclusivity and proportional representation, keeping in mind the rights of women, the disabled, Dalits, ethnic and indigenous people, sexual minorities and other similar groups (Singh, 2019:97). At least 33\% proportional representation of women in all walks of state affairs and access in parental property are the unique features of the constitution. Furthermore the constitutional reservations of $45 \%$ seats in government employment is another progressive arrangement. Provision of different specific commissions for the guarantee of inclusiveness is distinct from the previous constitution and any other constitution of the world. The provision of a constitutional bench for ten year from the commencement of the new constitution is another notable feature (Singh, 2019: 164-166). This kind of feature is a key feature and required in the plural country like Nepal.

\section{Strengths of the New Constitution}

Incorporation of adequate economic, social and cultural rights including group rights, empowerment of women and minorities and inclusiveness and proportional representation of all segments of Nepalese social life are the major attributes of the present constitution. The constituent assembly delivered to a new constitution adapting republicanism, federalism, secularism and inclusiveness on September 20, 2015. It made some progressive arrangements unlike the previous constitutions of Nepal. In order to flourish the language given by the mother, Article 6 
of the constitution has been provisioned that all the language given by the mother shall be the National Language. Moreover, the constitution of Nepal under Article 7 has envisaged that in addition to Nepali language, a province can select one or more national languages to be used by the people there. Nepal's federal structure divided into seven provinces and 753 local governments with clear lists of legislative powers for the center, provincial and local bodies is a special arrangement. The new constitution has transformed the century's long centralized unitary system of governance into federalism where three tiers of federal units work in vertical and horizontal order seem an advance form of federalization with the sources of powers secured in enumerated lists of the constitution is a positive breakthrough itself(Dhungel, 2017: 258). The new constitution has explicitly expressed the citizens' unrestrained rights to political pluralism and multiparty democracy.

The provision of fundamental rights embodied under part III Article 16 to 48 of the constitution are more progressive in nature. Right to information, right to communication, right to justice, right of victim of crime, right against torture, right to free legal aid, right to privacy, right to property, right to clean environment, right to language and culture, rights of women, rights of Dalits, right of senior citizens, right to social security, etc. are comparatively progressive arrangement under the present constitution of Nepal (LBMB, 2016: 9-26). More interestingly, right to privacy has been enlisted under the fundamental rights in Nepal which is quite different from the constitutional provision of the other countries of South Asia as they keep it under 'right to life and personal liberty' clause.

Amusingly, Nepal's new constitution has established distinct progressive elements for the empowerment of women in 
the country ensuring proportion representation of women as fundamental rights and guaranteeing at least $33 \%$ of representation in legislative body. The constitution is a compromising document of the political forces of the time. It can be amended if the situation demands. In fact, a constitution is supposed to be a living dynamic document which should be capable of addressing the future challenges, emerging aspirations of the people and changing context of the time (Tripathi, 2016: 117). Flexibility is the beauty of Nepalese constitution which can be achieved through desirable procedures.

\section{Weaknesses of the New Constitution}

Vague and clumsy preamble, disparity in matters of citizenship issues, enlistment of ambitious and unenforceable, politically influencing judicial structure are the major weaknesses bestowed under the present constitution of Nepal.

Obviously, the constitution is supposed to be a collective document of compromise among the major political powers of the time. In the same vein the present constitution of Nepal as a document has also addressed the interests and the concerns of the people. So the constitution has been confined within the limitations. So it cannot be detached from the criticism.

The Preamble of the constitution is too vague and so clumsy with the declarations of unnecessarily lengthy words and languages and political jargons. In fact it would be very short and concise. The federalism adopted in the country seems like imposition rather than the need of the country. Neither can it be justified from federalism theory of coming together nor going together. Probably, it will be more costly to a poor developing country like Nepal in the future. The matter of inclusion remains under debate. The provision of inclusion under Article 42 (1) of the present constitution contradicts with the provision of the interim 
constitution of Nepal and appears regressive due to the presence of mere inclusion instead of proportional inclusion provision of outgoing constitution.

The citizenship provision granted by the new constitution is progressive due to granting of citizenship of Nepal by descent on the basis of the name of mother or father specifying gender identity. But again there are dissatisfactions against the provision of the process for acquiring citizenship to a foreigner spouse of a Nepali woman unlikely the foreign women married to the Nepali guy can easily acquire the natural citizenship. The provision of the constitution which displays disparity against the Nepalese often marked as a regressive step. The Madhesi community and feminist groups of Nepalese society have shown their discontent on it.

Similarly, the enlistment of ambitious and unenforceable fundamental rights in the constitution is a degenerating backdrop. Some of the fundamental rights mentioned in part III Article 16 to 48 of the constitution are more ambitious and beyond the reach of the poor country like Nepal. They could be kept under principles and state policies and shifted to fundamental rights as per the economy of the country. Incorporation of such unenforceable rights in the constitution tends to distract from the reliability of the state (Tripathi, 2016). Article 47 of the constitution resembles a 3 years' time bond for the implementation of fundamental rights conferred by part III is against the principle of constitutionalism. Presenting a long list of the fundamental rights in the constitution and concurrently imposing limitations in the name of public welfare is a great fantasy of the constitution.

The provision of the appointment of the Judges of Judiciary are silently shadowed by the politics. Constitutional council 
and judicial council in which the dominant number of the board members from political background are entrusted for the appointment of the chief justice and other judges of the Supreme Court. So the judiciary of Nepal seems less independent and committed to the government of the day. This situation under the present constitution of Nepal is against the conviction of Article 14 (1) of International Covenant on Civil and Political Rights (1966) which enumerates, "Everyone shall be entitled to a fair and public hearing by a competent, independent and impartial tribunal established by law" (Lamichhane and Jyakhwo, 2019:147). Hitting with the points Dhungel rightly suggests "Courts should not be dragged in the political mess unduly created by political parties who may get tempted to dip their dirty fingers in the judicial regime" (Dhungel, 2017: 258). In independent judiciary like in the USA and India, the courts are entirely far from the influence of the executive and legislature and boldly strengthen civil rights and freedoms through judicial interpretations. But, the Nepalese judicial system within the border of the constitution still awaits under observation. Hence the discontented group of the country demand for the amendment of some specific ambiguous arrangements of citizenship, judicial council, constitutional court, social justice and inclusive provisions. "The main challenge the state have has been the high expectations of the people with limited resources on hand" (Gurung, 2018:46).

\section{Conclusion}

The constitution is a fundamental legal document of a country. It sets out the authority and rights of the government and the governed. The constitution of Nepal (2015) is the seventh constitution in the constitutional history of Nepal. The present Constitution of Nepal 2015 was built by the Constituent 
Assembly and approved by the significant majority of the House. The constitution is committed to the major ideals of liberal democracy and socialism.

Dynamism and flexibility, comprehensive catalogue of fundamental rights and inclusiveness and proportional representation are the major features of the Constitution of Nepal (2015) under the framework of republicanism, federalism, secularism and inclusiveness on which majority of the people of Nepal show their faith and loyalty. Incorporation of adequate economic, social and cultural rights including group rights, empowerment of women and minorities and inclusiveness and proportional representation of all segments of Nepalese social life are the major innovative attributes of the new Constitution of Nepal. Contrary to this some sections of Nepalese society especially Madhes-based parties, few ethnic communities and feminist group of Nepal keep their discontents on inclusivity, citizenship provision and constituency delineation provision of the constitution. Some intellectual societies put their remarks on ambitious and unenforceable fundamental rights bundled in part III of the constitution and also doubt over the independence of the judiciary where the judges are appointed through a judicial council with a dominant number of members associated with the government of the day.

However, the new Constitution of Nepal has allowed space for moving amendment to any Article except the provisions relating to self-rule of Nepal, sovereignty, territorial integrity and sovereignty vested in the people. The success of the Constitution depends upon how Nepal tackles and accommodates the issues of discontented groups and activities of both extreme rights and left political forces. The constitution is a document of compromise amongst the political forces of the time where the amalgamation 
of all interests and discontents is a great challenge. In a nutshell, the Constitution of Nepal deserves almost all qualities of a good constitution however the success of it within the laboratory of implementation still awaits under observation balancing between mutually contradictory philosophies of liberal ideals and socialism altogether within the Pandora of limited physical resources of the state on hand.

\section{References}

Bhattarai, S. K. (2073 B.S.). Nepalko Sambaidhanik tatha Prasasakiya Kanun. Kathmandu: Pairavi Prakashan.

Chaturvedi, S.K. (1992). Nepal: Internal politics and its constitution: New Delhi: Inter-India Publication.

Dahal, G.D. (2017). Constitution of Nepal and Political Development: Adoption and Challenges of Implication. Janapriya Journal of Interdisciplinary Studies, 17, 148159.

Davis, D., Cheadle, H. and Haysom, N. (1997). Fundamental Rights in the Constitution: Commentary and Cases. Kenwyn: Juta and Co, Ltd.

Dhungel, S. (2017). A Critical Note on Nepal's New Constitution. Supreme Bar Journal, 10(11), 251-258.

Grimm, D. (2017). Constitutionalism: Past, Present and Future. UK: Oxford University Press.

Gurung, P.S. (2018). Lived Experience of Federalism since the Election in 2017. A paper Presented on "The Conference on the Constitution of Nepal", 11-13 August 2018, Kathmandu: Kathmandu University School of Law/ The Southasia Trust.

Lamichhane, B.P. and Jyakhwo, M. (2019). Fundamentals of 
Human Rights. Kathmandu: Paravi Books.

LBMB (2016). The constitution of Nepal. Kathmandu: LBMB.

Meena, R.K and Bhattacharjee, D. (2016). Constitutional Development in Nepal, in Promod Jaiswal (Ed.) Constitutional Development in Nepal: Evolution, Development and Debates, New Delhi: GB Books.

Naidu, S.K (2016). Constitution building in Nepal. Delhi: Gaurav Book Centre Pvt.Ltd.

Sharma, A.R. (2020). Sustainable Development Goals and Human Rights in Nepali Context. Kathmandu:

National Human Rights Commission, Nepal.

Singh, S.K (2016). Nepal: From Monarchy to Democratic Constitution. Delhi: Prashant Publishing House

Singh, S. (2019). Nepal: International politics and its constitution. New Delhi: Surendra Publication.

Strong, C.F. (1973). Modern Political Constitutions, ( $8^{\text {th }}$ ED), London: Sidgwick and Jackson Ltd.

Subedi, S.P. (2017). Constitutional and political developments in Nepal are the challenges in implementation of the new Constitution. JOPA, Journal of Public Affairs, 9-11.

Tripathi, H.B. (2002). Fundamental Rights and Judicial Review in Nepal. Kathmandu: Pairavi Prakashan

Tripathi, H.B. (2016). The Constitution of Nepal: A critique. NJA law Journal 2016, pp.113-130, Kathmandu. 